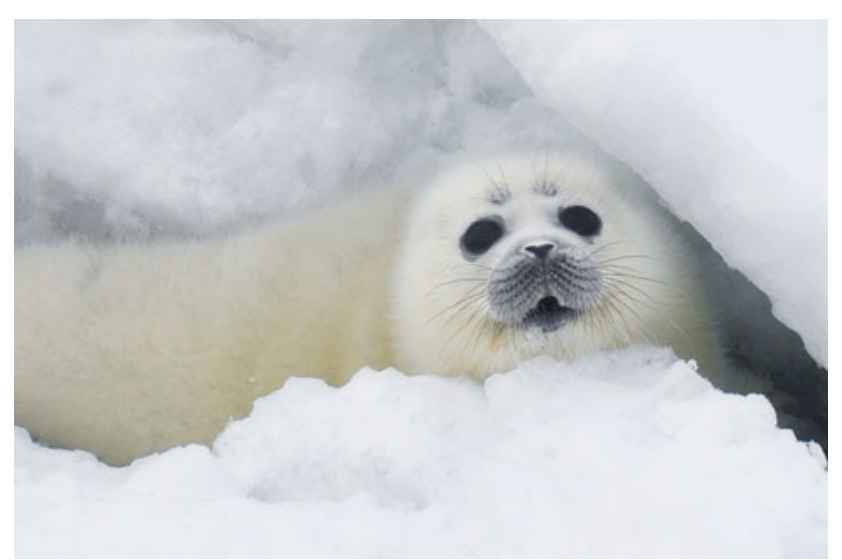

The Endangered Caspian seal Pusa caspica. Photo: Nataliya Shumeyko.

ERICH HOYT (10 orcid.org/0000-0001-6946-4055, erich.hoyt@ imma-network.org) Co-chair, IUCN Marine Mammal Protected Areas Task Force, and Whale and Dolphin Conservation Association, Chippenham, UK

This is an Open Access article, distributed under the terms of the Creative Commons Attribution licence CC BY 4.0.

\section{A range-wide conservation action plan for the European bison}

In 2004, the IUCN Species Survival Commission Bison Specialist Group published a European Bison Status Survey and Conservation Action Plan (Belousova et al., 2004, IUCN/SSC Action Plans for the Conservation of Biological Diversity, IUCN, Gland, Switzerland). By 2020, there were c. 6,800 European bison Bison bonasus in 47 free-ranging subpopulations across 10 countries, c. 500 in semi free-living conditions, and c. 1,70o in ex situ facilities. The 2020 IUCN Red List assessment (Plumb et al., 2020, The IUCN Red List of Threatened Species 2020, e.T2814A45156279) recategorized the species from Vulnerable to Near Threatened, with ongoing threats highlighted (low genetic diversity, small population size and habitat fragmentation). In early 2022, the Bison Specialist Group and European Bison Conservation Center will copublish a strategic status review, as noted by Olech et al. (Oryx, 2019, 53, 214).

Progress has been made in improving knowledge about the species and in implementing actions that have increased its abundance and distribution, yet there is a diversity of viewpoints on what future success for the species might look like. Consequently, the Bison Specialist Group, European Association of Zoos and Aquaria, European Bison Conservation Center, Rewilding Europe, WWF, Tierpark Berlin, Humboldt University-Berlin, and Polish Academy of Sciences-Mammal Research Institute have agreed to collaborate on a European Bison Range-wide Conservation Action Plan, facilitated by the IUCN Species
Survival Commission Conservation Planning Specialist Group. The Plan will adopt the One Plan approach, which emphasises participation by a broad range of stakeholders and integrates in situ and ex situ population management activities into a coherent set of conservation strategies and actions.

The Plan will follow the Conservation Planning Specialist Group's Species Conservation Planning Principles and Steps (CPSG, 2020, Species Conservation Planning Principles \& Steps. Version 1.o. IUCN SSC Conservation Planning Specialist Group, Apple Valley, USA), use the best available science and information to assess the prevailing circumstances, and recommend priority near-term actions (over 10 years) that advance the long-term strategic direction (over 100 years) towards recovery of the species within its historical range. The Plan will also consider how habitats outside the historical range could play a role in that recovery, considering possible future climatic and land-use changes that could influence the longer-term adaptability and resilience of the species. Key issues to be addressed include population viability through maintaining natural selection mechanisms; habitat availability and fragmentation; human-wildlife coexistence; metapopulation viability and management; genetics; integration of in situ and ex situ management; wildlife health; role of feeding, hunting and culling; climate change; policy and legislative consistency; captive breeding; and adaptive management. During 2022, the planning process will include stakeholder analyses, online and in-person workshops, and new population viability analyses. The Plan, to be published in 2023 , will provide a scientifically rigorous strategic framework to inform subsequent additional national and subregional plans and actions that collectively will contribute to achieving range-wide goals for the European bison.

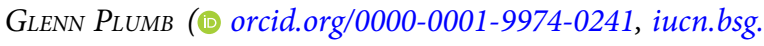
plumb@gmail.com) IUCN Species Survival Commission, Bison Specialist Group Chair, Livingston, USA

This is an Open Access article, distributed under the terms of the Creative Commons Attribution licence CC BY 4.0.

\section{Sea Turtle Conservancy dedicates new sea turtle field station in Parque Nacional Marino Isla Bastimentos, Panama}

The Sea Turtle Conservancy (formerly Caribbean Conservation Corporation) has been active in sea turtle conservation throughout the greater Caribbean since the 1950s. On 7 November 2021, Peter and Anne Meylan, research associates of the Sea Turtle Conservancy and the Smithsonian Tropical Research Institute, Cristina Ordoñez and other members of the Sea Turtle Conservancy, along with a host of beach monitors and other community members, dedicated a new field station on the Small Zapatilla Cay in the Bastimentos Island National Marine Park, Bocas del Toro Province, Panama. 